
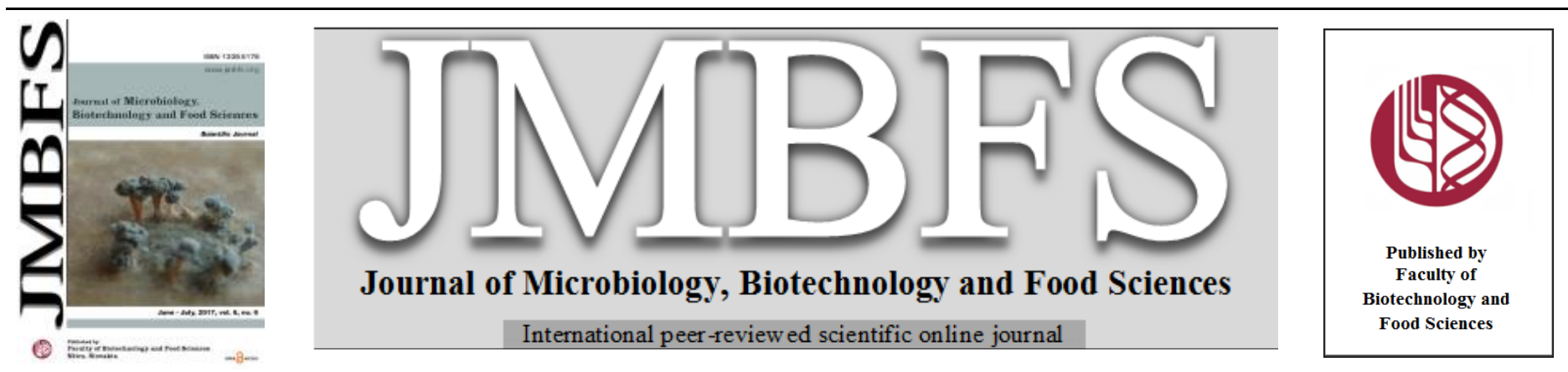

\title{
IMMOBILIZTION OF ORGANOPHOSPHORUS HYDROLASE ENZYME ON FERRIC MAGNETIC NANOPARTICLES AND INVESTIGATION OF IMMOBILIZED ENZYME STABILITY
}

\author{
Seyed Mortaza Robatjazi, Mohammadmostafa Reihani, Sanaze Mahboudi, Seyed mohammad Hasanpour, Mohammad Ali Nasiri \\ Khalili
}

Address(es): Seyed Mortaza Robatjazi,

Department of Bioscience and Biotechnology, Malek Ashtar University of Technology, Tehran, Iran, Tel/Fax: +9822974605 .

*Corresponding author: mailto:s_m_robatjazi@mut.ac.ir

doi: $10.15414 /$ jmbfs.2017.6.6.1295-1299

\section{ARTICLE INFO}

Received 6. 9. 2016

Revised 24. 4. 2017

Accepted 2. 5. 2017

Published 1. 6. 2017

Regular article

open ${ }_{\text {ACCESS }}$

\begin{abstract}
In the present study, organophosphorus hydrolase enzyme on Functionalized ferric magnetic nanoparticles was immobilized by the covalent binding method. The Optimized amount for parameters of $\mathrm{mg}$ EDAC $/ \mathrm{mg}$ nanoparticles, enzyme units $(\mathrm{U}) / \mathrm{mg}$ nanoparticles, reaction time, and $\mathrm{pH}$ were determined to be $6.125,0.1341,3 \mathrm{~h}$ and 6.15 respectively. The amount of immobilization yield according to the enzyme activity was obtained to be $70 \%$ and also the amount of immobilized enzyme on nanoparticles was $0.25 \mathrm{U} / \mathrm{mg}$ nanoparticles. Stability studies showed significant increase in immobilized enzyme stability at 4,25 and $45^{\circ} \mathrm{C}$. The stability of Immobilized enzyme showed a 6.3 -fold increase in comparison to free enzyme at $4^{\circ} \mathrm{C}$. The results demonstrated that the $\mathrm{pH}$ stability of the immobilized enzyme significantly increased in comparison with free enzyme. The immobilized enzyme was usable and recoverable for seven cycles. The results depicted that $80 \%$ of enzyme activity was retained after fifth cycle. FTIR test showed the covalent binding of enzyme to magnetic nanoparticles' surface and the modified enzyme magnetic nanoparticles property was superparamagnetic by vibrating sample magnetometer test.
\end{abstract}

\section{INTRODUCTION}

Organophosphorus compounds with respect to their widespread use in agriculture, expose food resources, water and even air to the pollution. Organophosphate compounds such as insecticide parathion (o,o-diethyl- $o-4$ nitrophenyl phosphorothioate), methyl parathion and diazinon, in spite of their extreme toxicity have been used in production of plant pesticides. Compared with the potential disadvantage of conventional methods, bioremediation would appear to be more attractive because it is far less disruptive and more costeffective (Lei et al., 2005). Some reports have shown that organophosphorus compounds are degraded by some bacteria. Pseudomonas diminuta MG (Serda et al., 1985) and a Flavobacterium sp. (ATCC 27551) (Sethunathan et al., 1973) have the ability to degrade a broad spectrum of organophosphorus triesters by virtue of a constitutively expressed organophosphorus hydrolase (Harper $\boldsymbol{e t}$ al., 1988). Organophosphorus hydrolase enzyme called OPH (E.C 3.1.8.1) is able to hydrolyze the ester bond of organophosphate compounds such as parathion and paraoxon but due to the instability of this enzyme in free mode bioremediation process or its application in hydrolysis or materials detection has faced many problems. The enzyme activity is dependent on the environmental variables, so the OPH enzyme after 5 hours incubation at room temperature in the aquatic environment loses about 50\% of its activity (Obare $\boldsymbol{e t}$ al., 2010; Robatjazi $\boldsymbol{e t}$ al., 2010). Biocatalysts immobilization processes are economically efficient and lead to development of the biological continuous processes. The unique physical properties of nanoparticles allow their application in many fields such as biomedicine (Atanasijevic et al., 2006: Gupta et al., 2005; Ito et al., 2005), sensor development (Katz et al., 2004), water purification (Savage et al., 2005) and environmental remediation (Liu, 2006; Tratnyek et al., 2006; Zhang, 2003). Superparamagnetism of magnetic nanoparticles (MNPs) is a sizedependent property that is useful for applications requiring manipulation of MNPs by an external magnetic field. Such particles do not retain any residual magnetism once the magnetic field is removed (Gupta et al., 2005; Ito et al., 2005). Using magnetic nanoparticles in biological processes and protein immobilization is considered one of the novel methods of immobilization. MNPs have found many applications in various processes due to their high specific surface area ratio, magnetic properties and special features (Wang et al., 2012). The large surface- area-to-volume ratio of a nanoparticle allows it to serve as an efficient carrier of biomolecules. This feature has resulted in the development of many biomolecule-nanoparticle (bio-NP) hybrids for biomedical applications in the diagnosis and localized treatment of disease (Atanasijevic et al., 2006: Gupta et al., 2005; Ito et al., 2005; Harris et al., 2006). MNP-enzyme conjugates (MNP-Es) represent a specific class of bio-NP conjugates that are of particular interest for biotechnological applications where high catalytic specificity, prolonged reaction time, and in some cases the ability to recycle an expensive biocatalyst is required (Alcalde et al., 2006; Swanson, 1999). The covalent bonding and ionic bonding are two methods of MNP binding to biomolecules. Covalent binding is a method that is widely used in the biopolymers immobilization. Covalent binding is usually carried out by direct biomolecule reactive groups binding or by binding to an intermediate. The purpose of this study is to immobilize OPH enzyme on MNP covalently and immobilization optimization and evaluation of storage stability of immobilized $\mathrm{OPH}$ enzyme.

\section{MATERIAL AND METHODS}

\section{Bacterial strain}

Flavobacterium ATCC 27551 was obtained from Microbial Type Culture Collection (MTCC, Chandigarh, India). OPH enzyme was then isolated and purified from bacteria (Brown, 1980).

\section{Magnetic nanoparticles and chemicals}

Utilized magnetic nanoparticles with dextran surface cover and $\mathrm{NH}_{2}$ agent with average size of $130 \mathrm{~nm}$ (amino-modified magnetic nanoparticles (AMN)), $\mathrm{N}$-(3 dimethylaminopropyl)- $N$-ethyl carbodiimide (EDAC) and 2-N-morpholinoethanesulfonic acid (MES) buffer and parathion were purchased from Micromode, Merck and Sigma Companies respectively. All of the experimental materials in this study were of high purity and were purchased from Fluka and Merck Companies.

\section{Immobilization of OPH enzyme on AMNs}

In order to Immobilize OPH enzyme on AMNs surfaces, $20 \mu \mathrm{l}$ of AMNs was transferred to a $2 \mathrm{ml}$ microtube. Ferric nanoparticles were then washed three times 
with MES buffer solution and suspended in $100 \mu 1$ of MES buffer solution. After shaking for one minute by putting permanent magnet under the micro tube for 12 minute(s) AMNs were separated from the solution. Then, a $100 \mu \mathrm{l}$ MES solution containing $0.7 \mathrm{mg}$ EDAC was added to the nanoparticles that had been suspended in the $100 \mu \mathrm{l}$ MES solution and mixed with shaker for 10 minutes. A $10 \mu \mathrm{l}$ stock enzyme solution with $2.2 \mathrm{U} / \mathrm{ml}$ activity was added to microtube containing active nanoparticles, then the microtube was incubated for $3 \mathrm{~h}$ at $4^{\circ} \mathrm{C}$ with $250 \mathrm{rpm}$. After the end of incubation, nanoparticles were washed three times with a $300 \mu \mathrm{l}$ PBS buffer solution and suspended with a $300 \mu \mathrm{l}$ PBS buffer solution in $\mathrm{pH}=8$

\section{Optimization process}

The optimum conditions for the covalent binding of OPH enzyme to AMNs surface were obtained using Taguchi experiment design method and Qualitek-4 software. This method allows observation and optimization of variables simultaneously. In the present study, a standard Taguchi L9 orthogonal array due to its ability to operate 4 parameters in 3 levels was chosen. Parameters and their levels for the covalent binding of OPH enzyme to AMNs are shown in Tab 1.

Table 1 Factors and level of parameters used in Taguchi experimental design.

\begin{tabular}{lccc}
\hline Factor & Level 1 & Level 2 & Level 3 \\
\hline $\begin{array}{l}\text { EDAC/AMN } \\
\text { ratio(w/w) }\end{array}$ & 2.45 & 6.126 & 15.313 \\
Enzyme/AMN & 0.0894 & 0.1341 & 0.1788 \\
ratio(U/mg) & 1.5 & 3 & 4.5 \\
Time (h) & 6 & 6.15 & 6.30 \\
pH & & & \\
\hline
\end{tabular}

\section{Evaluation of Immobilized enzyme stability}

Free and immobilized enzyme stability was determined by using relative activity calculation. The immobilized enzyme and the samples containing free enzyme as the observer were incubated at the same condition of $4,25,45^{\circ} \mathrm{C}$ and enzyme activity in different periods was determined intermittently. The acidity stability of both immobilized enzyme and free enzyme was determined at the same condition at $\mathrm{pH}$ range of $4-11$. The samples were incubated at $4^{\circ} \mathrm{C}$ for $3 \mathrm{~h}$. In order to determine activity of samples, first samples were incubated at $25^{\circ} \mathrm{C}$ and $\mathrm{pH}=8$ for 30 minutes then their activities were determined.

\section{Analytical methods}

The phosphotriesterase activity was measured on the basis of Spectrophotometric Assay method. The rate of ethyl-parathion hydrolysis was determined by measuring para-nitrophenol production (Robatjazi et al., 2010). For this purpose $150 \mu \mathrm{l}$ of solution containing immobilized enzyme and $150 \mu \mathrm{l}$ of PBS buffer at $\mathrm{pH}=8$ were mixed. Then $10 \mu \mathrm{l}$ of $50 \mathrm{mM} \mathrm{CoCl}{ }_{2}$ solution was added and the mixture was shaken for 30 minutes at room temperature. Next, $5 \mu$ of $40 \mathrm{mM}$ ethyl-parathion was added and p-nitrophenol production rate was determined by measuring the increase of absorbance rate at $410 \mathrm{~nm}$. One unit of phosphotriesterase activity (U) was defined as the amount of enzyme required to hydrolyze $1 \mu \mathrm{mol}$ of ethyl-parathion per minute at $30^{\circ} \mathrm{C}$ (as described previously in detail by Robatjazi et al. (2010)).

\section{VSM and FTIR}

Immobilized and free enzyme Sample spectrum was determined using FTIR spectroscopy. OPH enzyme was immobilized on AMNs by the determined optimized condition. Then, modified magnetic nanoparticles (enzyme-AMNs) and AMNs were freeze-dried for 24 hours at $-60^{\circ} \mathrm{C}$ (model Alpha 2-4 LSC; Martin Christ, Osterode, Germany). The Samples spectrums were measured from $450 \mathrm{~cm}^{-1}$ to $4000 \mathrm{~cm}^{-1}$. In order to perform the vibrating sample magnetometer (VSM) test, modified AMNs were washed twice with distilled water and then dried using freeze-drier on aluminum plates for 48 hours. VSM test measurement was carried out on magnetometer device (VSM, Kashan University, Iran) by changing the magnetic field from +8000 to -8000 .

\section{RESULTS AND DISCUSSION}

Optimization experiment results are shown in Tab 2 on the basis of enzyme specific activity in $\mathrm{mg}$ of nanoparticles. Each parameter's effect and its level effect is shown in figure 1 , according to the obtained results it can be deduced that $\mathrm{pH}$ parameters, enzyme $(\mathrm{U}) / \mathrm{mg}_{\mathrm{AMN}}$ ratio, $\mathrm{mg}_{\mathrm{EDAC}} / \mathrm{mg}_{\mathrm{AMN}}$ and incubation time for enzyme covalent binding on the surface of AMNs were levels of 2, 2, 2, 2 respectively.

Results showed that 3 hours incubation time had the most positive effect on enzyme-AMN reaction. The enzyme to magnetic nanoparticle ratio and $\mathrm{mg}_{\text {EDAC }} / \mathrm{mg}_{\mathrm{AMN}}$ and $\mathrm{pH}$ for enzyme covalent binding on AMNs surface had 15, 45 and 65 percent effectiveness on immobilization. Immobilization process was carried out in optimized condition. Optimized condition for covalent binding by amino groups for incubation time, $\mathrm{U} / \mathrm{mg}$ MNP ratio, $\mathrm{mg}$ EDAC $/ \mathrm{mg}$ MNP ratio, and $\mathrm{pH}$, was determined $3 \mathrm{~h}, 0.1341,6.125 \mathrm{U} / \mathrm{mg}$, and 6.5 respectively.

Table 2 The results of immobilized enzyme activity in $\mathrm{L}_{9}$ orthogonal array of the Taguchi experimental design.

\begin{tabular}{|c|c|c|}
\hline Trial & Factors & Results \\
\hline 1 & $\begin{array}{c}\mathrm{mg} \mathrm{EDAC}_{\mathrm{E}} / \mathrm{mg}_{\mathrm{AMN}} \operatorname{ratio}(\mathrm{w} / \mathrm{w})=2.45, \mathrm{U}_{\mathrm{enzyme}} / \mathrm{mg}_{\mathrm{AMN}} \\
\operatorname{ratio}(\mathrm{U} / \mathrm{w})=0.0894\end{array}$ & 0.038 \\
\hline 2 & $\begin{array}{c}\mathrm{mg} \mathrm{EDAC} / \mathrm{mg}_{\mathrm{AMN}} \operatorname{ratio}(\mathrm{w} / \mathrm{w})=2.45, \mathrm{U}_{\text {enzyme }} / \mathrm{mg}_{\mathrm{AMN}} \\
\operatorname{ratio}(\mathrm{U} / \mathrm{w})=0.1341\end{array}$ & 0.076 \\
\hline 3 & $\begin{array}{c}\mathrm{mg} \mathrm{EDAC} / \mathrm{mg}_{\mathrm{AMN}} \operatorname{ratio}(\mathrm{w} / \mathrm{w})=2.45, \mathrm{U}_{\text {enzyme }} / \mathrm{mg}_{\mathrm{AMN}} \\
\operatorname{ratio}(\mathrm{U} / \mathrm{w})=0.1788\end{array}$ & 0.032 \\
\hline 4 & $\begin{array}{l}\mathrm{mg} \text { EDAC } / \mathrm{mg}_{\text {AMN }} \operatorname{ratio}(\mathrm{w} / \mathrm{w})=6.126 \\
\mathrm{U}_{\text {enzyme }} / \mathrm{mg}_{\text {AMN }} \operatorname{ratio}(\mathrm{U} / \mathrm{w})=0.0894\end{array}$ & 0.061 \\
\hline 5 & $\begin{array}{l}\mathrm{mg} g_{\text {EDAC }} / \mathrm{mg}_{\text {AMN }} \operatorname{ratio}(\mathrm{w} / \mathrm{w})=6.126 \\
\mathrm{U}_{\text {enzyme }} / \mathrm{mg}_{\text {AMN }} \operatorname{ratio}(\mathrm{U} / \mathrm{w})=0.1341\end{array}$ & 0.043 \\
\hline 6 & $\begin{array}{l}\mathrm{mg} \text { EDAC } / \mathrm{mg}_{\text {AMN }} \operatorname{ratio}(\mathrm{w} / \mathrm{w})=6.126 \\
\mathrm{U}_{\text {enzyme }} / \mathrm{mg}_{\text {AMN }} \operatorname{ratio}(\mathrm{U} / \mathrm{w})=0.1788\end{array}$ & 0.089 \\
\hline 7 & $\begin{array}{c}\mathrm{mg} \text { EDAC } / \mathrm{mg}_{\text {AMN }} \operatorname{ratio}(\mathrm{w} / \mathrm{w})=15.313 \\
\mathrm{U}_{\text {enzyme }} / \mathrm{mg}_{\text {AMN }} \\
\operatorname{ratio}(\mathrm{U} / \mathrm{w})=0.0894\end{array}$ & 0.027 \\
\hline 8 & $\begin{array}{c}\mathrm{mg}_{\text {EDAC }} / \mathrm{mg}_{\text {AMN }} \operatorname{ratio}(\mathrm{w} / \mathrm{w})=15.313 \\
\mathrm{U}_{\text {enzyme }} / \mathrm{mg}_{\text {AMN }} \operatorname{ratio}(\mathrm{U} / \mathrm{w})=0.1341\end{array}$ & 0.078 \\
\hline 9 & $\begin{array}{c}\mathrm{mg} \mathrm{EDAC} / \mathrm{mg}_{\text {AMN }} \operatorname{ratio}(\mathrm{w} / \mathrm{w})=15.313 \\
\mathrm{U}_{\text {enzyme }} / \mathrm{mg}_{\text {AMN }} \operatorname{ratio}(\mathrm{U} / \mathrm{w})=0.1788\end{array}$ & 0.048 \\
\hline
\end{tabular}



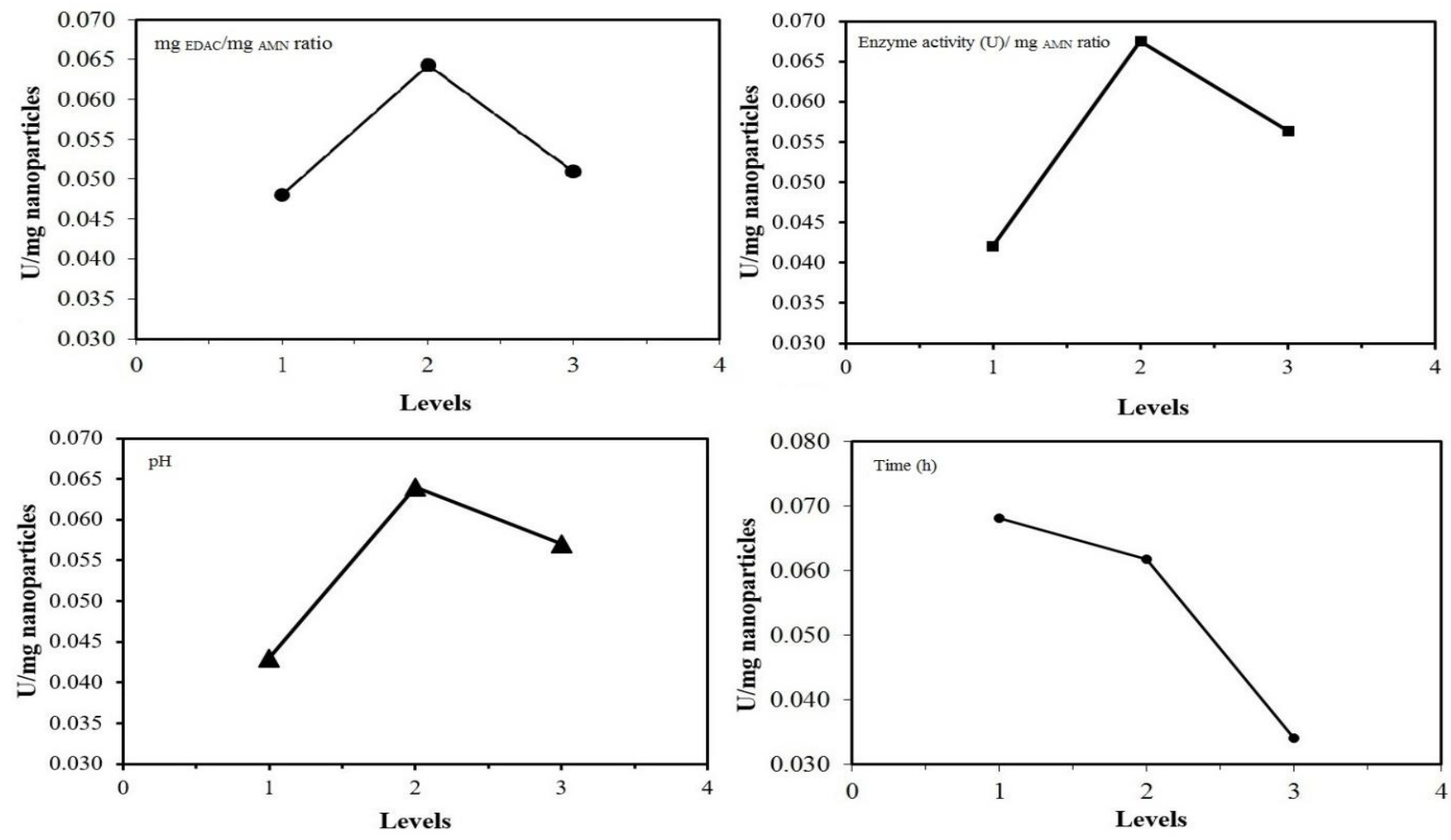

Figure 1 Average response levels for different parameters

Experiments were performed several times using the optimized conditions, and the results were in good agreement with those predicted from Taguchi experiment design. Results showed in optimized condition that amount of immobilized enzyme on nanoparticles was $0.25 \mathrm{U} / \mathrm{mg}_{\text {nanoparticles }}$ with about $70 \%$ efficiency. The obtained results were in good agreement with studies performed by Jiang et al. (2008) . In a similar study by Kuo et al. (2012) immobilization efficiency was reported $58.3 \%$ for Lipase enzyme immobilization, Highest obtained activity was reported 20 unit per gram and in similar studies by Sahoo et al. (2011), urease enzyme immobilization was reported $57 \%$ on ferric magnetic nanoparticles.

Figure 2 shows the $\mathrm{pH}$ stability of immobilized enzyme. The $\mathrm{pH}$ stability increased for the immobilized enzyme compared with the free enzyme. As the $\mathrm{pH}$ shifted towards the alkaline or acidic conditions, the enzyme activity of the immobilized enzyme remained higher compared with the free enzyme. This may be due to the protection of the enzyme by MNPs against extreme $\mathrm{pH}$ values. The remaining enzyme activity of the immobilized enzyme and the free enzyme after $8 \mathrm{~h}$ of incubation at $\mathrm{pH} 4$ were $78 \%$ and $20 \%$ respectively.

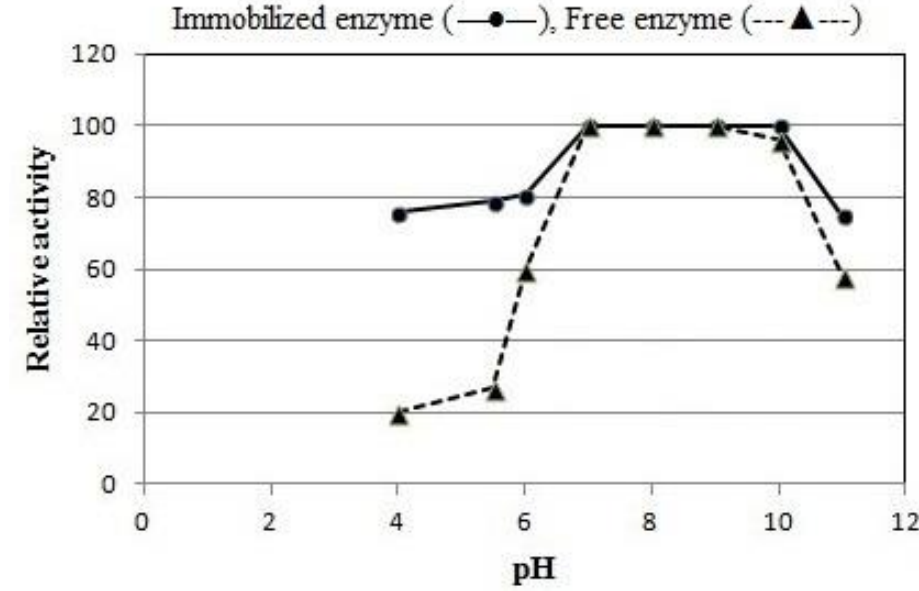

Figure 2 pH stability of immobilized enzyme

Stability studies showed significant increase in immobilized enzyme stability at 4,25 and $45^{\circ} \mathrm{C}$. The results are shown in the figure 3.The results show after $120 \mathrm{~h}$ of incubation at $4{ }^{\circ} \mathrm{C}$ that the relative activity has been $91 \%$ and $43 \%$ for the immobilized enzyme and free enzyme, respectively (figure 3-a). Immobilized enzyme stability was determined 6.3-fold increase in comparison to free enzyme at $4{ }^{\circ} \mathrm{C}$. A $50 \%$ reduction in the initial enzyme activity of the immobilized enzyme determined after 135 and $62 \mathrm{~h}$ of incubation at 25 and $45^{\circ} \mathrm{C}$, respectively, (figure $3-b, c)$. The results demonstrated that coupling of $\mathrm{OPH}$ to AMNs enhanced the enzyme thermal stability at 4,25 and $45^{\circ} \mathrm{C}$. The Immobilized enzyme saved $87.7 \%$ of its activity for more than 10 days at $4{ }^{\circ} \mathrm{C}$. 

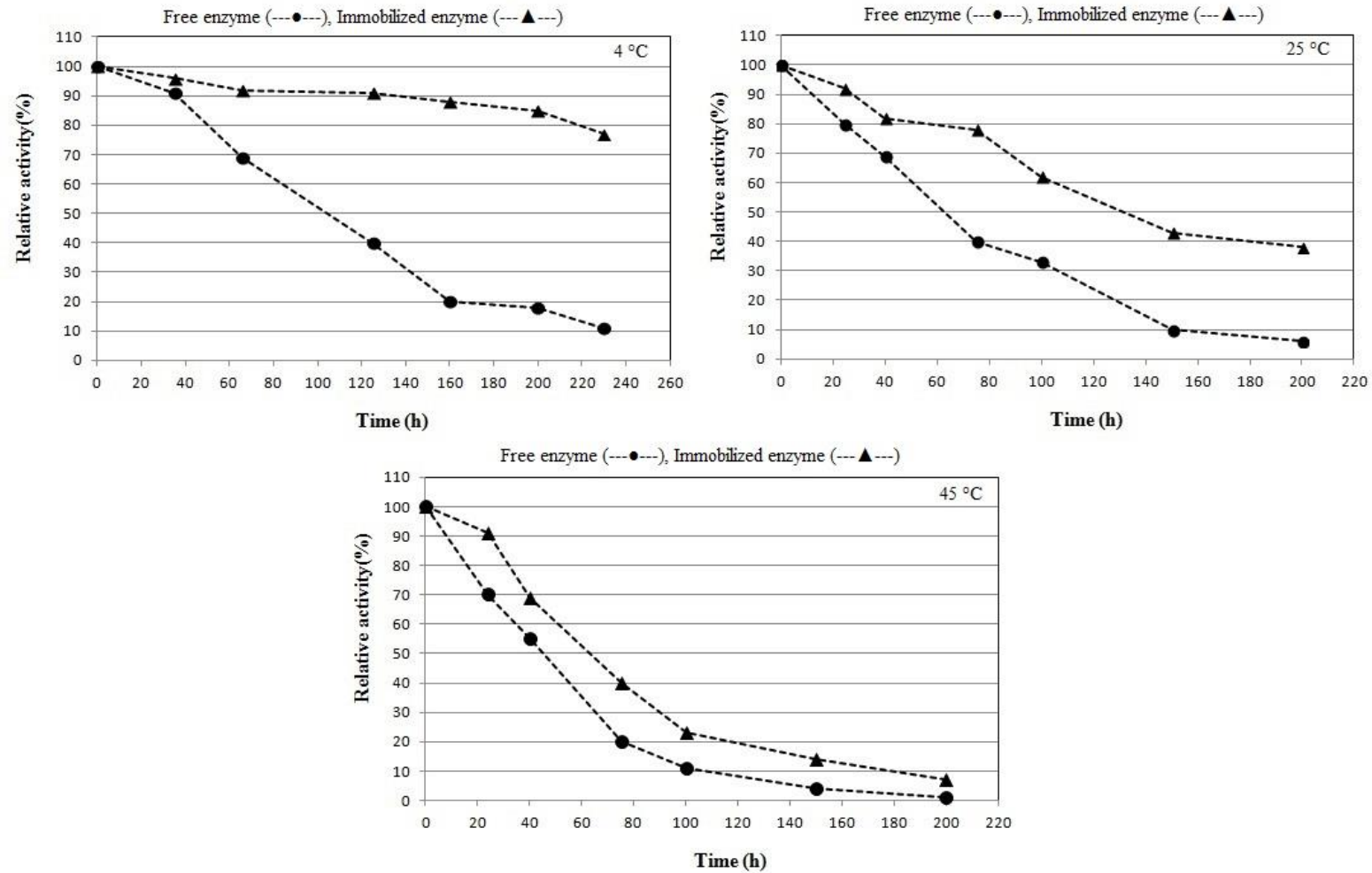

Figure 3 Enzyme thermal stability of immobilized enzyme

The immobilized enzyme was usable and recoverable for about seven cycles. The activity of immobilized enzyme was assayed up to seven cycles. The investigation depicted that $96 \%$ enzyme activity was retained after third cycle and $80 \%$ after fifth cycle. According these results, the relative enzyme activity was decreased $23 \%$ after seven cycles (figure 4 ).

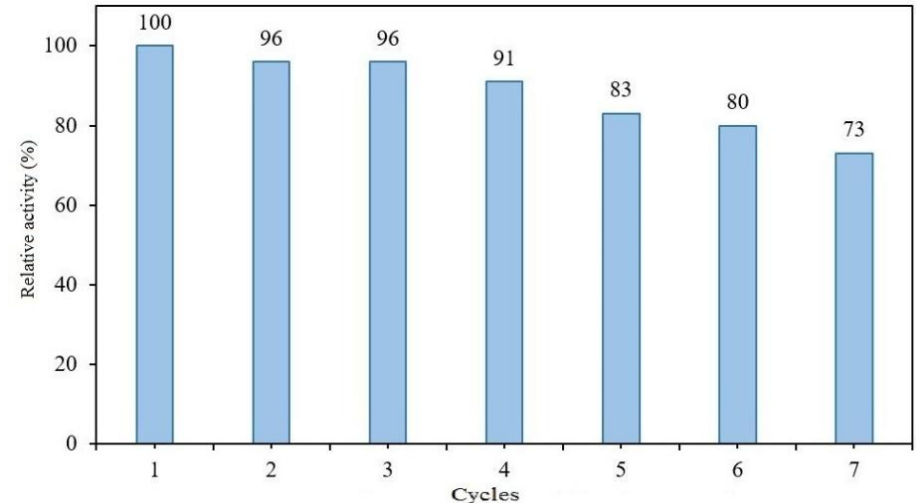

Figure 4 Relative activity of immobilized enzyme after each cycle of use

FTIR test results confirmed the covalent bonding between enzyme and magnetic nanoparticles agent groups (figure 5). On this basis, bonds are visible at $571 \mathrm{~cm}^{-1}$ and $1635 \mathrm{~cm}^{-1}$ which proves the enzyme bonding to nanoparticles such as reported by Teste et al. (2010) previously. VSM test results showed that the enzyme coated magnetic nanoparticles retain their superparamagnetic nature during the immobilization process and only about $10 \%$ of the magnetic property is decreased (figure 6).
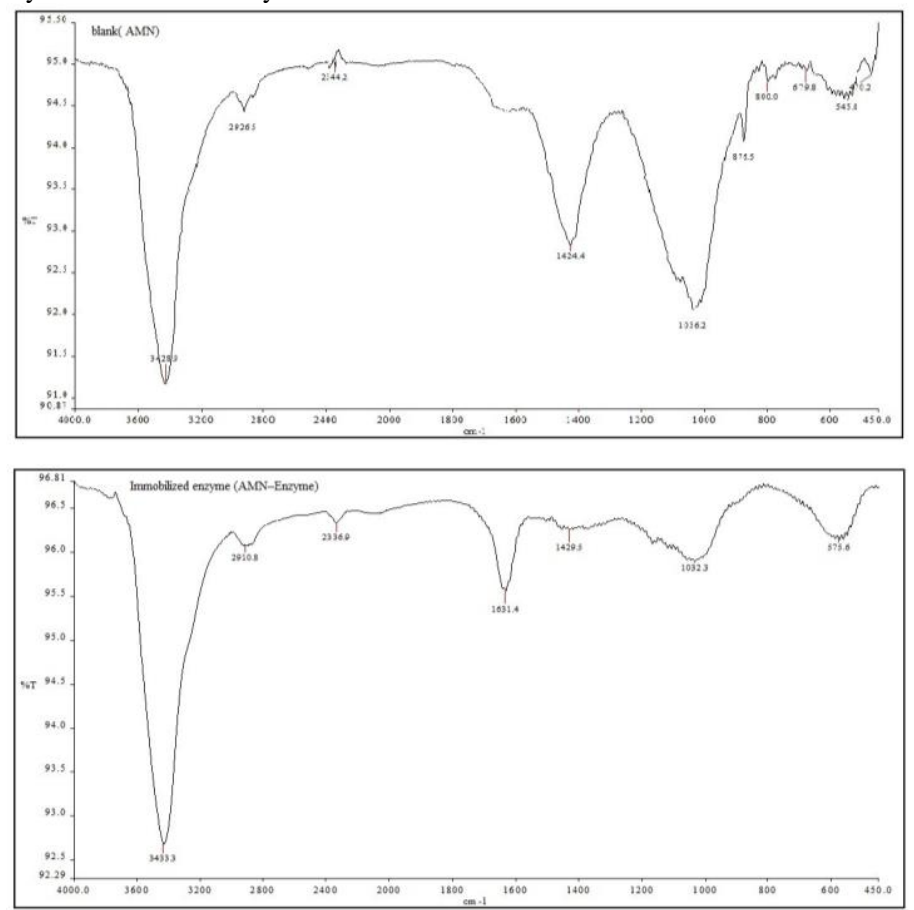

Figure 5 FTIR spectroscopy spectrum of Immobilized enzyme, a: blank ( AMN), b: Immobilized enzyme (AMN-Enzyme) 


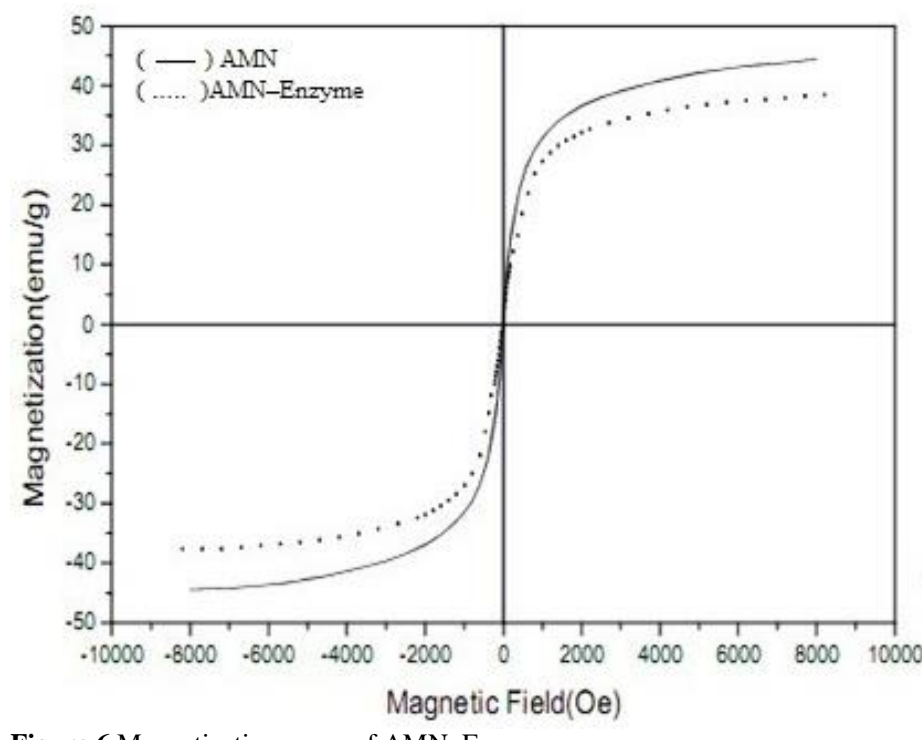

Figure 6 Magnetization curve of AMN-Enzyme

\section{CONCLUSION}

In the present study, OPH have been linked to the magnetic nanoparticles's surface by the covalent coupling method. Best conditions were determined for enzyme binding to the magnetic nanoparticle's surface. The thermal stability of immobilized enzyme on the magnetic nanoparticle's surface showed 6.3-fold, 1.4-fold and 1.1-fold increase in comparison to free enzyme after $120 \mathrm{~h}$ of incubation at 4,25 and $45^{\circ} \mathrm{C}$ respectively. Immobilized enzyme on magnetic nanoparticle's surface can simply be separated with a magnet which leads to reuse and sequential use of enzymes. The enzyme-magnetic nanoparticles can be utilized in applications such as biodegradation, biosensing and they are also appropriate for development of nanoscale smart technologies.

\section{REFRENCES}

Alcalde, M., Ferrer, M., Plou, F.J., \& Ballesteros, A. (2006). Environmental biocatalysis: from remediation with enzymes to novel green processes. Trends Biotechnology, 24, 281-287. http://dx.doi.org/10.1016/j.tibtech.2006.04.002

Atanasijevic, T., Shusteff, M., Fam, P., \& Jasanoff, A. (2006). Calcium-sensitive MRI contrast agents based on superparamagnetic iron oxide nanoparticles and calmodulin. Proceedings of the National Academy of Sciences of the United States of America, 103, 14707-14712. http://dx.doi.org/10.1073/pnas.0606749103 Brown, K.A., (1980). Phosphotriesterases of Flavobacterium sp. Soil Biology and Biochemistry;12:105-12. http://dx.doi.org/10.1016/0038-0717(80)90044-9 Gupta, A.K., \& Gupta, M. (2005). Synthesis and surface engineering of iron oxide nanoparticles for biomedical applications. Biomaterials, 26, 3995-4021. http://dx.doi.org/10.1016/j.biomaterials.2004.10.012

Harper, L.L., McDaniel, C.S., Miller, C.E., \& Wild, J.R. (1988). Dissimilar plasmids isolated from Pseudomonas diminuta $M G$ and a Flavobacterium sp. (ATCC 27551) contain identical opd genes. Applied and environmental microbiology, 2586-2589. http://www.ncbi.nlm.nih.gov/pmc/articles/PMC204325

Harris, T.J., von Maltzahn, G., Derfus, A.M., Ruoslahti, E., \& Bhatia, S.N (2006). Proteolytic Actuation of Nanoparticle Self-Assembly. Angewandte $\begin{array}{llll}\text { Chemie International } & \text { Edition, 45, 3161-3165. }\end{array}$ http://dx.doi.org/10.1002/anie.200600259

Ito, A., Shinkai, M., Honda, H., \& Kobayashi, T. (2005). Medical application of functionalized magnetic nanoparticles. Journal of Bioscience and Bioengineering, 100, 1-11. http://dx.doi.org/10.1263/jbb.100.1

Jiang, Y., Guo, C., Xia, H., Mahmood, I., Liu, C., \& Liu, H. (2009). Magnetic nanoparticles supported ionic liquids for lipase immobilization: Enzyme activity in catalyzing esterification. Journal of Molecular Catalysis B: Enzymatic, 58, 103-109. http://dx.doi.org/10.1016/j.molcatb.2008.12.001

Katz, E., \& Willner, I. (2004). Integrated Nanoparticle-Biomolecule Hybrid Systems: Synthesis, Properties, and Applications. Angewandte Chemie International Edition, 43, 6042-6108. http://dx.doi.org/10.1002/anie.200400651

Kuo, C., Liu, Y., Chang, C., Chen, J., Chang, C., \& Shieh, C. (2012). Optimum conditions for lipase immobilization on chitosan-coated $\mathrm{Fe}_{3} \mathrm{O}_{4}$ nanoparticles. $\begin{array}{lll}\text { Carbohydrate } \quad \text { Polymers, } & \text { 257, }\end{array}$ http://dx.doi.org/10.1016/j.carbpol.2011.11.026

Lei, Y., Mulchandani, A., \& Chen, W. (2005). Improved Degradation of Organophosphorus Nerve Agents and p-Nitrophenol by Pseudomonas putida JS444 with Surface-Expressed Organophosphorus Hydrolase. Biotechnology Progress, 21, 678-681. http://dx.doi.org/10.1021/bp0495901

Liu. W-T. (2006). Nanoparticles and their biological and environmental applications. Journal of Bioscience and Bioengineering, 102, 1-7.
Obare, SO, De, C, Guo, W, Haywood , T.L., Samuels, T.A., Adams, C.P., ...\& Fletcher K. (2010). Fluorescent chemosensors for toxic organophosphorus pesticides: A review. Sensors, 10, 7018-7043. http://dx.doi.org/10.1263/jbb.102.1 Robatjazi, S.M., Shojaosadati, S.A., Khalilzadeh, R., \& Farahani, E.V. (2010) Optimization of the covalent coupling and ionic adsorption of magnetic nanoparticles on Flavobacterium ATCC 27551 using the Taguchi method.

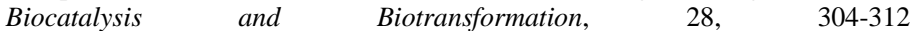
http://dx.doi.org/10.3109/10242422.2010.516390

Sahoo, B., Sahu, S.K., \& Pramanik, P. (2011). A novel method for the immobilization of urease on phosphonate grafted iron oxide nanoparticle. Journal of Molecular Catalysis B: Enzymatic, 69, 95-102. http://dx.doi.org/10.1016/j.molcatb.2011.01.001

Savage, N., \& Diallo, M.S. (2005). Nanomaterials and Water Purification: Opportunities and Challenges. Journal of Nanoparticle Research, 7, 331-342. http://dx.doi.org/10.1007/s11051-005-7523-5

Serdar, C.M., \& Gibson, D.T. (1985). Enzymatic Hydrolysis of Organophosphates: Cloning and Expression of a Parathion Hydrolase Gene from Pseudomonas diminuta. Nature Biotechnology, 3, 567-571. http://dx.doi.org/10.1038/nbt0685-567

Sethunathan, N., \& Yoshida, T. (1973). A Flavobacterium sp. that degrades diazinon and parathion. Canadian Journal of Microbiology, 19, 873-875. http://dx.doi.org/10.1139/m73-138

Swanson, P.E. (1999). Dehalogenases applied to industrial-scale biocatalysis. Current Opinion in Biotechnology, 10, 365-369. http://dx.doi.org/10.1016/S0958 1669(99)80066-4

Teste, B., Vial, J., Descroix, S., Georgelin, T., Siaugue, J.M., Petr, J., ...\& Hennion, M.C. (2010). A chemometric approach for optimizing protein covalent immobilization on magnetic core-shell nanoparticles in view of an alternative $\begin{array}{lll}\text { immunoassay. } & \text { Talanta, } & \text { 1703-1710 }\end{array}$ http://dx.doi.org/10.1016/j.talanta.2010.03.027

Tratnyek, P.G., \& Johnson, R.L. (2006). Nanotechnologies for environmental cleanup. Nanotoday 1, 44-48. http://dx.doi.org/10.1016/S1748-0132(06)70048-2

Wang, J., Zhao, G., Li, Y., Liu, X., \& Hou, P. (2013). Reversible immobilization of glucoamylase onto magnetic chitosan nanocarriers. Applied Microbiology and Biotechnology, 97, 681-692. http://dx.doi.org/10.1007/s00253-012-3979-2

Zhang, W.X. (2003). Nanoscale iron particles for environmental remediation: an overview. Journal of Nanoparticle Research, 5, 323-332. http://dx.doi.org/10.1023/A:1025520116015 